\title{
ASUPAN MAKAN DENGAN KEJADIAN OBESITAS PADA REMAJA DI SMA KATOLIK SANTO ANDREAS PALU
}

\author{
${ }^{1)}$ Lisnawati ${ }^{2)}$ Ansar ${ }^{3)}$ Lilik Taufiq Abdurrahman \\ ${ }^{1,2,3)}$ Politeknik Kesehatan Kementerian Kesehatan Palu
}

\begin{abstract}
ABSTRAK
Latar Belakang : Obesitas pada remaja semakin meningkat termasuk di Indonesia. prevalensi obesitas pada usia 15 tahun atau lebih sebesar 7,3\%. Faktor asupan makan penyebab terjadinya obesitas pada remaja sebagian besar disebabkan oleh konsumsi energi dan lemak tinggi. Tujuan penelitian : diketahuinya Hubungan Asupan makan Dengan Kejadian Obesitas Di SMA Katolik Santo Andreas Palu. Metode Penelitian : jenis penelitian observasional dengan menggunakan rancangan cross-sectional dengan pendekatan kuantitatif. pengukuran variabel bebas dan variabel terikat dilakukan dalam waktu bersamaan pada suatu periode tertentu. Sampel : 77 orang remaja yang dilakukan di SMA Katolik Santo Andreas Palu. Penilaian status gizi menggunakan indikator indeks massa tubuh menurut umur (IMT/U) data berat badan (BB) dan tinggi badan (TB) dikumpulkan dengan pengukuran antropometri. Sedangkan pola konsumsi dilakukan dengan metode Food Recall 24 jam. Hipotesa dianalisis menggunakan uji Chi-Square dan uji Fisher Exact dengan tingkat kepercayaan (a) 5\%. Hasil penelitian : menujukkan bahwa dari 77 responden, 14 (18,2\%) diantaranya berstatus gizi obesitas sedangkan $63(81,8 \%)$ tidak obesitas, sebagian besar remaja yang obes $(92,9 \%)$ memiliki orang tua dengan riwayat obesitas. Proporsi obesitas lebih banyak pada remaja yang mengkonsumsi energi cukup (61,5\%), proporsi obesitas lebih banyak pada remaja yang mengkonsumsi protein lebih $(41,4 \%)$ dan proporsi obesitas lebih banyak pada remaja yang mengkonsumsi lemak cukup (58,8\%). Kesimpulan : terdapat hubungan antara asupan makan (asupan energi, asupan protein, asupan lemak) dengan kejadian obesitas pada remaja di SMA Katolik santo andreas palu. Saran : untuk mengkonsumsi makanan sesuai dengan prinsip gizi seimbang.
\end{abstract}

Kata Kunci : Obesitas, Energi, Protein, Lemak, Remaja

\section{PENDAHULUAN}

Peningkatan

kemakmuran

masyarakat Indonesia di perkotaan yang

disebabkan oleh keberhasilan

pembangunan di bidang ekonomi dan kemajuan teknologi pangan menyebabkan perubahan gaya hidup yang menjurus ke westernisasi dan sedentary. Hal itu mengakibatkan perubahan asupan makan masyarakat tradisional yang rendah karbohidrat, tinggi serat, dan rendah lemak berubah ke asupan makan baru yang tinggi karbohidrat, rendah serat, dan tinggi lemak. Perubahan asupan makan dan aktivitas fisik ini berakibat kepada semakin banyaknya penduduk yang mengalami masalah overweight dan obesitas khususnya pada remaja (Almatsier, 2011:84).

Menurut Badan Kesehatan Dunia, World Health Organisation (WHO), obesitas adalah akumulasi lemak yang abnormal atau berlebihan sehingga dapat merusak kesehatan. Indeks massa tubuh (IMT) secara umum digunakan untuk mengklasifikasikan derajat obesitas. Berdasarkan hal tersebut, rekomendasi IMT untuk kawasan AsiaPasifik yaitu seseorang dikategorikan gemuk (overwight) apabila IMT-nya $>23$ $\mathrm{kg} / \mathrm{m}^{2}$ dan obesitas apabila IMT-nya $>25$ $\mathrm{kg} / \mathrm{m}^{2}$.Obesitas telah menjadi masalah 
kesehatan yang mewabah hingga ke seluruh penjuru dunia dan memberikan dampak yang sangat serius terhadap kesejahteraan penduduk, ekonomi, dan militer sehingga dapat mengancam keamanan dan ketahanan nasional. Obesitas juga termasuk dalam lima faktor risiko terhadap kejadian kematian di seluruh dunia, yaitu sebanyak 2,8 juta orang dewasa per tahunnya meninggal dikarenakan mengalami obesitas dan kegemukan (WHO, 2011).

Berdasarkan Badan Litbangkes Kemenkes RI (2010), secara nasional masalah kegemukan pada anak umur 612 tahun masih tinggi yaitu 9,2\% atau masih di atas 5,0\%. Prevalensi kegemukan pada anak laki-laki umur 612 tahun $10,7 \%$ lebih tinggi dari prevalensi pada anak perempuan yaitu $7,7 \%$. Pada remaja usia 13-15 tahun adalah sebesar $2,5 \%$ dan pada remaja usia 16-18 tahun sebesar 1,4\%. Prevalensi kegemukan di propinsi Sulawesi Tengah pada anak SD usia 612 tahun adalah 5,9\%, pada remaja SMP usia 13-15 tahun sebesar 0,8\%, dan pada remaja SMA usia 16-18 tahun adalah sebesar 1,3\%. Berdasarkan tempat tinggal prevalensi kegemukan lebih tinggi di perkotaan dibandingkan dengan prevalensi di pedesaan. Pada anak umur 6-12 tahun di perkotaan $10,4 \%$ dan di pedesaan $8,1 \%$. Pada remaja usia 13-15 tahun di perkotaan sebesar $3,2 \%$ dan di pedesaan $1,7 \%$ serta pada remaja usia 16-18 tahun di perkotaan sebesar $1,8 \%$ dan di pedesaan sebesar 0,9\% (Kemenkes RI, 2010).

Obesitas disebabkan karena faktor yang kompleks yaitu genetik, biologis, tingkah laku (asupan makan) dan budaya. Obesitas pada anak dan remaja berhubungan dengan kebiasaan makan yang buruk, kurangnya aktifitas fisik, riwayat keluarga, penyakit, obat-obatan, masalah rumah tangga, dan beban psikologis (AACAP, 2011.)
Studi pendahuluan di SMA Katolik Santo Andreas Palu siswa mengatakan bahwa merasa obesitas karena berat badannya berlebih pada saat menimbang berat badan, terlihat siswa yang gemuk bahkan diantaranya ada yang sangat gemuk, akibatnya siswa kesulitan dalam beraktifitas terutama dalam berolahraga. Tujuan penelitian ini untuk mengetahui hubungan asupan makan dengan kejadian obesitas pada remaja di SMA Katolik Santo Andreas Palu.

\section{BAHAN DAN METODE PENELITIAN}

Penelitian ini merupakan jenis penelitian observasional, menggunakan rancangan cross-sectional dengan pendekatan kuantitatif. Pada penelitian rancangan cross-sectional, pengukuran variabel bebas dan variabel terikat dilakukan dalam waktu bersamaan pada suatu periode tertentu (Gordis, 2004).

Penelitian ini dilaksanakan di SMA Katolik Santo Andreas Palu, Penelitian ini dilaksanakan dari bulan januari sampai juni 2015 dengan pengumpulan data dilakukan bertahap pada tanggal 11 Mei sampai 18 Juni 2015.

Populasi dalam penelitian ini adalah seluruh siswa/siswi kelas $X$, dan XI di SMA Katolik Santo Andreas Palu sebanyak 174 orang. Subjek penelitian adalah siswa/siswi SMA Katolik Santo Andreas Palu dengan kriteria inklusi; 1) berusia 15-18 tahun, 2) Aktif sekolah, 3) tidak sedang melakukan diet khusus yang berkaitan dengan penurunan berat badan. Besar sampel dengan rumus Lameshow yaitu 77 orang.

\section{HASIL}

\section{Analisis Univariat}

Asupan energi, protein dan lemak dalam penelitian ini menggunakan 3 variabel diantaranya, kurang, cukup, dan lebih. asupan dikatagorikan kurang jika $<80 \%$ AKG, cukup jika 80$110 \%$ AKG dan lebih jika >80\% AKG. 
Tabel 1

Distribusi Frekuensi berdasarkan Asupan Energi, Protein dan Lemak pada

Remaja di SMA Katolik Santo Andreas Palu Tahun 2015

\begin{tabular}{ccc}
\hline Variabel & $\begin{array}{c}\text { Frekuensi } \\
\text { (n=77) }\end{array}$ & $\%$ \\
\hline Asupan Energi & 64 & 83,1 \\
Kurang & 13 & 16,9 \\
Cukup & 0 & 0 \\
Lebih & & \\
Asupan Protein & 18 & 23,4 \\
Kurang & 30 & 39,0 \\
Cukup & 29 & 37,7 \\
Lebih & & \\
Asupan Lemak & 60 & 77,9 \\
Kurang & 17 & 22,1 \\
Cukup & 0 & 0 \\
Lebih & & \\
\hline
\end{tabular}

Berdasarkan tabel 1. dapat dilihat bahwa sebagian besar responden memiliki asupan energi kurang sebesar 83,1\%.

Asupan protein ditemukan paling banyak berada pada kategori cukup sebesar 39,0\% dan Lebih sebesar $37,7 \%$. sebagian besar responden memiliki asupan lemak kurang yaitu $77,9 \%$.

\section{Analisis Bivariat}

Analisis bivariabel untuk melihat hubungan antara asupan dengan obesitas dilakukan dengan menggunakan uji chi-square, jika syarat chi-square tidak terpenuhi maka dilakukan dengan fisher exact. Hasil analisis bivariat dapat dilihat pada tabel dibawah ini.

Tabel 2

Hasil Analisis Bivariabel Hubungan Asupan Energi dengan Kejadian Obesitas Pada Remaja SMA Katolik Santo Andreas Palu

\begin{tabular}{|c|c|c|c|c|c|c|c|}
\hline \multirow{3}{*}{ Variabel } & \multicolumn{4}{|c|}{ Status Obesitas } & & & \multirow{3}{*}{$\begin{array}{c}\text { P Value } \\
\text { (Fisher Exact) }\end{array}$} \\
\hline & \multicolumn{2}{|c|}{$\begin{array}{c}\text { Tidak } \\
\text { Obesitas }\end{array}$} & \multicolumn{2}{|c|}{ Obesitas } & \multicolumn{2}{|c|}{ Total } & \\
\hline & $\mathbf{n}$ & $\%$ & $\mathbf{n}$ & $\%$ & $\mathbf{n}$ & $\%$ & \\
\hline \multicolumn{8}{|l|}{ Asupan Energi } \\
\hline Kurang & 58 & 90,6 & 6 & 9,4 & 64 & 100 & \\
\hline Cukup & 5 & 38,5 & 8 & 61,5 & 13 & 100 & 0,000 \\
\hline \multicolumn{8}{|l|}{ Asupan Protein } \\
\hline Kurang & 18 & 100,0 & 0 & 0,0 & 18 & 100 & \\
\hline Cukup & 28 & 93,3 & 2 & 6,7 & 30 & 100 & 0,000 \\
\hline Lebih & 17 & 58,6 & 12 & 41,4 & 29 & 100 & \\
\hline \multicolumn{8}{|l|}{ Asupan Lemak } \\
\hline Kurang & 56 & 93,3 & 4 & 6,7 & 60 & 100 & \\
\hline Cukup & 7 & 41,2 & 10 & 58,8 & 17 & 100 & 0,000 \\
\hline
\end{tabular}


Berdasarkan tabel 2. dapat dilihat dari 64 remaja yang memiliki asupan energi yang kurang sebesar $90,6 \%$ tidak obesitas, sebaliknya dari 13 remaja yang memiliki asupan energi cukup ditemukan 61,5\% diantaranya obesitas. Hasil uji fisher exact menunjukan bahwa $\mathrm{P}<0,05$.

Berdasarkan perhitungan nilai expected count setiap kolom yang telah dilakukan, didapatkan lebih dari $20 \%$ kolom yang memiliki nilai expected count $<5$, karena penelitian ini menggunakan tabel $2 \times 2$ sehingga uji fisher's exact dipilih sebagai uji statistik. Dari hasil uji fisher's exact didapatkan nilai $\mathrm{P}=0,000$ ( $p$ value $<0,05)$ dalam uji statistik apabila $\mathrm{P}<$ 0,05 menunjukan bahwa ada hubungan yang bermakna antara asupan energi dengan kejadian obesitas di SMA Katolik Santo Andreas Palu.

Pada remaja yang memiliki asupan protein lebih, sebesar $41,4 \%$ obesitas, remaja yang memiliki asupan protein cukup, sebesar $6,7 \%$ obesitas dan remaja yang memiliki asupan protein kurang tidak ada yang obesitas. Hasil uji chi-square menunjukan bahwa $\mathrm{P}<0,05$.

Berdasarkan perhitungan nilai expected count setiap kolom yang telah dilakukan didapatkan kurang dari $20 \%$ kolom yang memiliki nilai expected count $<5$. Dari hasil uji chisquare menunjukan bahwa $\mathrm{P}<0,05$ dan berarti ada hubungan yang bermakna antara asupan protein dengan kejadian obesitas di SMA Katolik Santo Andreas Palu.

Pada tabel 2. dapat dilihat dari 60 remaja yang memiliki asupan lemak yang kurang, sebesar 93,3\% tidak obesitas, sebaliknya dari 10 remaja yang memiliki asupan lemak cukup ditemukan $58,8 \%$ diantaranya obesitas. Hasil uji fisher exact menunjukan bahwa $\mathrm{P}<0,05$.

Berdasarkan perhitungan nilai expected count setiap kolom yang telah dilakukan, didapatkan lebih dari $20 \%$ kolom yang memiliki nilai expected count $<5$, sehingga uji fisher's exact di pilih sebagai uji statistik yang digunakan. Dari hasil uji fisher's exact didapatkan nilai $\mathrm{P}=$ 0,000 ( $p$ value $<0,05$ ) dalam uji statistik apabila $P<0,05$ menunjukan bahwa ada hubungan yang bermakna antara asupan protein dengan kejadian obesitas di SMA Katolik Santo Andreas Palu.

\section{PEMBAHASAN}

Penelitian ini dilakukan dengan cara pengumpulan data terolah dengan menggunakan formulir food recall pada responden yang berjumlah 77 orang. Setelah dilakukan pengolahan dan analisis data maka dibahas sebagai berikut:

\section{Kejadian Obesitas}

Hasil penelitian ini menunjukan kejadian obesitas sebesar $18,2 \%$. Hal ini disebabkan karena jam pelajaran yang cukup padat sehingga remaja cenderung banyak mengkonsumsi makanan cepat saji dan jarang mengkonsumsi jenis makanan yang seimbang baik disekolah maupun di rumah, dan juga karena adanya pengaruh dari teman-teman sebaya, sehingga remaja cenderung mengkonsumsi makanan siap saji.

Menurut Palilingan (2010), banyak sekali resiko gangguan kesehatan yang dapat terjadi pada anak atau remaja yang mengalami obesitas. Anak dengan obesitas dapat mengalami masalah dengan sistem jantung dan pembuluh darah (kardiovaskuler) yaitu hipertensi dan dislipidemia (kelainan pada kolesterol). Bisa juga mengalami gangguan fungsi hati dimana terjadi peningkatan SGOT dan SGPT serta hati yang membesar. Bisa juga berbentuk batu empedu dan penyakit kencing manis (diabetes mellitus). Pada sistem pernapasan dapat terjadi 
gangguan fungsi paru, mengorok saat tidur dan sering mengalami tersumbatnya jalan nafas (obstructive sleep apnea).

Penelitian yang dilakukan di SMA Katolik Cendrawasih Makassar oleh Aflah tahun 2014 dan didapatkan prevalensi obesitas yang juga tinggi, bahkan jauh lebih tinggi daripada yang diperoleh dalam penelitian ini yaitu mencapai $50 \%$ sementara dalam penelitian ini hanya $18,8 \%$. Menurut asumsi peneliti perbedaan ini cukup wajar mengingat bahwa kota makassar lebih cepat terpapar dengan modernisasi yang mengakibatkan risiko kejadian obesitas lebih besar dibandingkan kota palu.

2. Hubungan Asupan Energi, Protein dan Lemak Dengan Kejadian Obesitas

Asupan energi yang ditemukan dalam penelitian ini adalah cukup dan kurang saja, asupan energi yang kurang sebanyak $83,1 \%$. Sedangkan asupan energi yang cukup sebesar $16,9 \%$. Asupan protein yang ditemukan dalam penelitian ini adalah kurang, cukup dan lebih. asupan protein kurang sebanyak $23,4 \%$, asupan protein cukup sebanyak $39,0 \%$ dan asupan protein lebih sebanyak 37,7\%. Adapun asupan lemak yang ditemukan dalam penelitian ini adalah cukup dan kurang saja, asupan lemak yang kurang sebanyak $77,9 \%$. Sedangkan asupan lemak yang cukup sebanyak $22,1 \%$.

Berdasarkan hasil analisis uji hipotesis bivariat diperoleh hasil bahwa $\mathrm{P}<0,05$ yang mengindikasikan bahwa ada hubungan antara asupan energi, asupan protein, dan asupan lemak dengan kejadian obesitas pada remaja. Dalam penelitian ini beberapa responden yang memiliki asupan makan yang kurang ternyata memiliki status obesitas, menurut asumsi peneliti hal ini dapat dikaitkan dengan faktor keturunan yang mana dalam penelitian ini sebesar 43,3\% orang tua obesitas, dan faktor lain yang diduga-duga adalah rendahnya aktifitas fisik yang dilakukan, sebagaimana kita ketahui bahwa aktifitas fisik yang sangat rendah dapat memicu penimbunan lemak.

Energi diperlukan untuk kelangsungan proses di dalam tubuh seperti proses peredaran dan sirkulasi darah, denyut jantung, pernafasan, pencernaan, proses fisiologis lainnya, untuk bergerak atau melakukan pekerjaan fisik. Energi dalam tubuh dapat timbul karena adanya pembakaran karbohidrat, protein dan lemak, karena itu agar energi tercukupi perlu pemasukan makanan yang cukup dengan mengkonsumsi makanan yang cukup dan seimbang.

Kelebihan energi terjadi bila konsumsi energi melalui makanan melebihi energi yang dikeluarkan. Kelebihan energi ini akan diubah menjadi lemak tubuh. Akibatnya, terjadi berat badan lebih atau kegemukan. Kegemukan bisa disebabkan oleh kebanyakan makan, dalam hal kabrohidrat, lemak maupun protein, tetapi juga karena kurang bergerak. Kegemukan dapat menyebabkan gangguan dalam fungsi tubuh, merupakan risiko untuk menderita penyakit kronis, seperti diabetes mellitus, hipertensi, penyakit jantung koroner, penyakit kanker, dan dapat memperpendek harapan hidup (Yati, 2010).

Protein bagi tubuh adalah sebagai zat pembangun, misalnya pada anak-anak sangat berperan untuk perkembangan tubuh dan sel otaknya. Sedangkan pada orang dewasa, apabila terjadi luka, memar dan sebagainya, maka protein dapat membangun kembali sel-sel yang rusak. Makanan yang tinggi protein biasanya tinggi lemak sehingga dapat dapat menyebabkan obesitas. 
Kelebihan protein tidak baik, karena dapat mengganggu metabolisme protein yang berada di hati. Ginjal pun akan terganggu tugasnya, karena bertugas membuang hasil metabolisme protein yang tidak terpakai. Jika kadar protein terlalu tinggi maka kalsium dapat keluar dari tubuh. Dan ini merupakan penyebab osteoporosis. Karena protein merupakan makanan pembentuk asam, kelebihan asupan protein akan meningkatkan kadar keasaman tubuh, khususnya keasaman darah dan jaringan. Kondisi ini disebut asidosis. Gangguan pencernaan, seperti kembung, sakit mag, sembelit, merupakan gejala awal asidosis (Pradana, 2012).

Kekurangan lemak

mengakibatkan perubahan pada komposisi asam lemak di berbagai jaringan, terutama membran sel. Selain itu terjadi penurunan efisiensi produksi energi di dalam sel. Konsumsi berlebih lemak akan mengakibatkan kegemukan karena kadar energi di dalam lemak lebih dari 2 kali kadar energi di dalam karbohidrat. Rasa makanan berlemak yang umumnya enak, cenderung mendorong konsumsi berlebih. Kegemukan berkaitan dengan timbulnya penyakit kronis seperti jantung dan pembuluh darah dan diabetes melitus (Akhmad, 2013).

Hubungan asupan energi, protein dan lemak dalam penelitian ini sejalan dengan peryataan yang dikemukakan oleh Departemen Gizi dan Kesehatan Masyarakat, FKM UI 2011 yang menyatakan bahwa obesitas terjadi karena ketidakseimbangan antara konsumsi energi dengan kebutuhannya sehingga terjadi kelebihan energi yang selanjutnya disimpan dalam bentuk jaringan lemak. Pada keadaan normal jaringan lemak ditimbun didalam jaringan subkutan dan jaringan tirai usus (omentum).

Untuk asupan protein diperoleh bahwa 100,0\% remaja yang memiliki asupan protein kurang berstatus gizi tidak obesitas. Dan 93,3\% remaja yang memiliki asupan protein cukup bersatatus gizi tidak obesitas. Sedangkan $41,4 \%$ remaja yang memiliki asupan protein lebih berstatus gizi obesitas.

Hasil Penelitian ini sejalan dengan penelitian yang dilakukan oleh Aflah pada tahun 2014, yang mendapatkan ada hubungan yang signifikan antara asupan protein dengan kejadian obesitas dengan $\mathrm{P}=$ 0,001 . Asupan makanan tinggi protein pada remaja diduga terkait dengan rasanya yang lebih disukai. Selain itu remaja cenderung menghindari makanan berlemak dengan mengalihkannya pada makanan berprotein tinggi dengan harapan bahwa makanan tersebut tidak akan menyebabkan kelebihan berat badan.

Sedangkan untuk asupan lemak diperoleh bahwa 93,3\% remaja yang memiliki asupan lemak kurang berstatus gizi tidak obesitas. Sedangkan 58,8\% remaja yang memiliki asupan lemak cukup berstatus gizi obesitas.

Penelitian di Amerika dan Finlandia menunjukkan bahwa kelompok dengan asupan tinggi lemak mempunyai risiko peningkatan berat badan 1,7 kali lebih besar dibanding kelompok dengan asupan rendah lemak. Keadaan ini disebabkan karena makanan berlemak mempunyai energy density lebih besar dibandingkan makanan yang mengandung protein dan karbohidrat. Lemak mempunyai kapasitas penyimpanan yang tidak terbatas. Kelebihan asupan lemak tidak diiringi peningkatan oksidasi lemak sehingga sekitar 96\% lemak 
akan disimpan dalam jaringan lemak (Daud, 2014)

Kecenderungan yang dapat dilihat dari hasil penelitian ini adalah pola makan yang berlebih dapat menjadi faktor terjadinya obesitas. Obesitas terjadi jika seseorang mengonsumsi energi melebihi jumlah energi yang dibakar. Pada hakikatnya, tubuh memerlukan asupan energi untuk kelangsungan hidup dan aktivitas fisik, namun untuk menjaga berat badan perlu adanya keseimbangan antara energi yang masuk dengan energi yang keluar. Keseimbangan energi yang terjadi dapat mengarah pada kelebihan berat badan dan obesitas. Sehingga para remaja perlu mengkonsumsi pola makan denga prinsip gizi seimbang dan juga menambah aktifitas fisik.

\section{KESIMPULAN}

Berdasarkan hasil penelitian yang telah dilakukan dapat disimpulkan :

1) Prevalensi obesitas pada remaja di SMA Katolik Santo Andreas Palu sebesar $18,2 \%$.

2) Ada hubungan antara asupan energi, protein dan lemak dengan kejadian obesitas di SMA Katolik Santo Andreas Palu.

\section{SARAN}

Berdasarkan hasil penelitian yang telah dilakukan, dapat disarankan: Kepada Remaja SMA Katolik Santo Andreas Palu agar mengkonsumsi makanan sesuai dengan aturan pola makan gizi seimbang sesuai kebutuhan tubuh dan perbanyak aktifitas fisik utamanya olah raga. bagi Sekolah agar dapat bekerjasama dengan dinas kesehatan agar dapat melakukan pemantauan status gizi remaja dengan memperhatikan asupan makanan yang seimbang sehingga kejadian obesitas dapat terpantau.

\section{DAFTAR PUSTAKA}

Aflah, R.R. 2014. Hubungan Pola Makan Dengan Kejadian Obesitas Pada
Remaja Di SMA Katolik

Cendrawasih. Makasar: Skripsi S1

Gizi, Fakultas Kesehatan

Masyarakat Universitas

Hasanuddin.

Akhmad. 2013. Akibat Kekurangan dan Kelebihan Lemak. Diunduh dari: http://akhmad113.mywapblog.com. diakses tanggal 26 Juni 2015

Almatsier, S. 2011. Gizi Seimbang Dalam Daur Kehidupan. Jakarta:PT Gramedia Pustaka Utama.

Badan Litbangkes Kemenkes RI, 2010. Riset Kesehatan Dasar 2010. Jakarta

Daud, H. 2014. Hubungan Presentase Lemak Tubuh Dengan Profil Lipid Pada Remaja Obesitas di Kota Makassar. Makassar: Tesis S2 Biomedik, Fakultas Kedokteran Universitas Hasanuddin.

Departemen Gizi dan Kesehatan Masyarakat FKM UI. 2011. Gizi dan Kesehatan Masyarakat. Jakarta. PT. Raja Grafindo Persada

Gordis, L. 2004. Epidemiology (third edition). W.B Saunders Company; . Pennsylvania

Kemenkes RI. 2010. Riset Kesehatan Dasar (Riskesdas) 2010. Jakarta

Kemenkes RI. 2013. Riset Kesehatan Dasar (Riskesdas) 2013. Jakarta

Palilingan, P. 2010. Obesitas Pada AnakAnak. Diunduh dari: http//:beingmom.org.id.diakses tanggal: 26 Juni 2015.

Persatuan Ahli Gizi Indonesia. 2009. Kamus Gizi. Jakarta:Kompas

Pradana, E. 2012. Akibat Kekurangan dan Kelebihan Protein. Diunduh dari:

http://blackelektrick.blogspot.com.d iakses tanggal: 28 Juni 2015.

SMA Katolik Santo Andreas Palu. 2014. Data Siswa. Palu 
Yati NS. 2010. Akibat Kekurangan dan Kelebihan Energi. Diunduh dari: http://yati-thinksmart.blogspot.com. diakses tanggal: 28 Juni 2015
WHO. 2011. Childhood overweight and obesity. Diunduh dari:

http://www.who.int/dietphysicalacti vity/childhood/en/.diakses tanggal: 28 September 2014 